\title{
Torrefied Cogon grass: Effects of torrefaction on fuel properties of solid and condensate products
}

\author{
Alvin Garcia Palanca ${ }^{a}$, Rizalinda L. De Leon ${ }^{\mathrm{b}}$, Wilfredo I. Jose ${ }^{\mathrm{c}} \mathrm{a}^{*}$ \\ ${ }_{a, b, \& c}$ College of Engineering University of the Philippines Diliman, Melchor Hall Rocess St. Diliman, \\ Quezon City 1101, Philippinnes
}

\begin{abstract}
Torrefaction is a thermal pretreatment process used to produce solid fuel by heating biomass below $300^{\circ} \mathrm{C}$ under anoxic conditions. This pretreatment process improves the fuel characteristics of Cogon grass, and its energy density was comparable to that of sub-bituminous class B and C coals.

Sun-dried Cogon grass was torrefied in a fabricated batch torrefaction reactor, and their solid and organic condensate products were analyzed. A response surface methodology was used to examine the effects of the torrefaction reaction temperature, feed size, reaction time, and Cogon grass parts (CPs) on energy density, mass yield, and energy yield of the solid products as well as the effects of reaction temperature and reaction time on the energy density and mass yield of the organic condensate. The mass yield decreases as the reaction temperature is increased, whereas it increases as the feed shifts from leaves to nodes, from $54 \%$ at $250{ }^{\circ} \mathrm{C}$ to $43 \%$ at $285^{\circ} \mathrm{C}$ and $39 \%$ using leaves to $60 \%$ using nodes. The energy yield increases from $50 \%$ to $82 \%$ as the feed shifts from leaves to nodes. This is, however, compensated by an increase of energy density by $34 \%$.

In addition, the energy density of the condensed gas products can be predicted using the four process parameters as an input variable on the surface response model for the energy density of condensed organic volatiles.
\end{abstract}

Keywords: torrefaction, biomass, biofuels, Cogon grass, renewable energy, energy resources

\section{Introduction}

The Philippines is an emerging economy in Southeast Asia [1]. The economic growth of the Philippines is reflected in its increasing energy needs, which also translates into a higher electricity demand. It is estimated that $31.6 \%$ of the oil produced worldwide in 2014 is sourced from countries in the Middle East, and $37 \%$ of this oil production is exported to Asia [2]. In 2015, the Philippines imported 328,000 barrels of crude oil per day for its energy needs, which makes our country the tenth largest oil importer in the Asian and Pacific region [3]. Our country's power systems can be best described as dependent on imported conventional fossil fuels to generate electricity. The price of fossil fuels and problems with climate change, environmental degradation, and pollution resulting from the continued use of fossil fuels have driven developing countries, such as the Philippines, to explore for alternative energy resources.

\subsection{Background}

Biomass can provide a variety of raw materials for the energy, metallurgical, and chemical industries. Biomass is the only renewable energy that can directly substitute coal in many applications (e.g., gasification and electricity production) [4]. Biofuels have the potential to replace a substantial part of conventional fossil fuels by $\sim 10 \%$ by 2030 [5]. The conversion of biomass to solid biofuels, such as

\footnotetext{
* Manuscript received July 25, 2017; revised December 2, 2017.

Alvin Garcia Palanca. Tel.: +63-9153643502; E-mail address: alvingarciapalanca@ gmail.com

doi: $10.12720 /$ sgce.7.1.1-12
} 
carbonization, has been an established cottage industry since thousands of years. It provided early people with charcoal, which is the first convenient solid fuel and a feedstock for iron extraction [6]. The torrefaction process has been used in a host of industries for tea and coffee making, but only in recent years, it has caught the attention of the power industry for the production of a coal substitute from biomass [6].

Conversion of lignocellulosic biomass into a solid biofuel is an attractive biomass option because its feedstock for biofuel conversion does not compete directly with food production and can be bred particularly for energy purposes [5]. Although biomass is a clean and a renewable energy resource, raw biomass is not an ideal solid fuel because of its poor fuel characteristics; it is typically heterogeneous in quality and nature and is particularly available in a low energy density form with relatively high moisture content. Torrefaction has the potential to address these issues by improving the characteristics of biomass. Torrefaction is defined as a thermochemical process conducted under an inert or a limited oxygen environment, wherein biomass is slowly heated within a specified temperature range and the temperature is maintained for a stipulated time such that it results in the near-complete degradation of its hemicellulose content while maximizing the mass and energy yield of the solid product [6]. Torrefactionis sometimes confused with related processes such as roasting, slow- and mild-pyrolysis, wood cooking, and high temperature drying; however, the motivation and process conditions of these processes are different [6] [7]. Similar to pyrolysis, torrefaction primarily maximizes liquid production while minimizing the char yield. Carbonization, contrast, maximizes the fixed carbon and minimizes the hydrocarbon content in the solid product, whereas torrefaction process maximizes the energy and mass yield with a reduction in $\mathrm{H} / \mathrm{C}$ and $\mathrm{O} / \mathrm{C}$ ratios.

Torrefied biomass can be utilized in three different energy market segments: large-scale power production, industrial heating, and residential or district heating [8]. The conversion process used can either be co-firing, co- or stand-alone gasification, or stand-alone combustion. The advantage of torrefaction is that it can be used in older and existing pulverized coal-fired power plants. Since these installations have not been designed for biomass co-firing originally, significant capital expenditure can be saved for the modification of the plant when torrefied biomass is co-fired instead of untreated biomass [15]. Torrefied biomass is known to have almost similar fuel properties to that of lignite coal, which results in the financial advantages of torrefied biomass over raw or untreated biomass. The relative low moisture content, good grindability, and attractive $\mathrm{C} / \mathrm{H} / \mathrm{O}$ ratios make torrefaction an interesting pretreatment technology for gasification. For a gasifier using biomass, the particle size and moisture content are critical factors for good operation [8].

\subsection{Related literature}

Various studies have been conducted on torrefaction, which are mainly focused on wood species [9][10][11], energy crops such as Canary grass and Miscanthus [12], forest residues [13], and agricultural residues (e.g., wheat straws, coconut leaves, and bagasse) [6][14]. Majority of previous studies on torrefaction are on torrefied solid products, and few have analyzed the potential of condensable gases produced during torrefaction that can be combusted to provide additional energy resources by measuring their heating values. However, there have been no studies on the torrefaction of Cogon grass or on the fuel characterization of both sun-dried and torrefied Cogon grass.

Cogon grass [Imperata cylindrica (L.) Beauv.] is a rhizomatous perennial grass that has infested $\sim 200$ million hectares of land in Asia and 500 million hectares worldwide [15]. It is a serious pest throughout the tropical and sub-tropical regions of the world and is ranked as the seventh most troublesome weed worldwide [16]. Cogon grass has little utility except for thatch, short-term forage production, and soil stabilization. Cogon grass is usually found on soils with low $\mathrm{pH}$, fertility, and organic matter and is highly leached. It is also well adapted to frequently disturbed ecosystems, such as areas wherein timber harvesting, grazing, weed control, or fire has occurred. It also thrives well on infertile soils due to its low nutrient demand and high nutrient uptake efficiency [17]. The ecological resiliency of Cogon grass and its ability to regenerate from any manmade or natural disturbance make it a preferred energy crop that can be 
used as a feedstock for the production of solid biofuel resources using the torrefaction process. The application of torrefaction has been extended to the possibility of using Cogon grass as a local energy crop to yield solid and liquid biofuels via the torrefaction process using a wall-particle conduction batch torrefaction reactor. The torrefied Cogon grass can serve as a replacement for coal or as a feedstock for large-scale power production, industrial heating, and residential or district heating. This research can contribute to the database of biomass fuel characterization by providing information about the sun-dried and torrefied Cogon grass high heating value (HHV), moisture content, ash content, volatile matter content, elemental composition, and chemical composition. This information is essential to planning and controlled manipulation of energy conversion processes using Cogon grass-derived biofuel products, which can serve as an alternative local energy resource for the Philippines. In addition, the revenue from Cogon grass-derived products (Torrefied Cogon grass) will be crucial for rural development and will enhance the energy crop production in the Philippines without jeopardizing our country's food and feed supply since Cogon grass can grow on undernourished agricultural land and does not deplete soil nutrients.

\section{Theoretical Framework}

The torrefaction process for Cogon grass involves heating it in a limited oxygen environment between $200^{\circ} \mathrm{C}$ and $300^{\circ} \mathrm{C}$ to allow its depolymerization at a specific reaction time and at a desired maximum reaction temperature. Variable process parameters that may influence the torrefaction process using the batch torrefaction reactor are the reaction temperature (RT), reaction time (Rt), feed size (FZ), and Cogon grass plant parts $(\mathrm{CP})$.

A two-stage experiment is adopted to determine the initial values of the process parameters used in the fabricated batch torrefaction reactor under which the next stage is conducted based on the lowest and highest condition for each variable process parameter to be considered in the design of the experiment (DOE).

Two-level factorial design is used as a design strategy for this experimental study to evaluate the impact or effect of one or more factors without concern for the extraneous variables or subjective judgments. The experiment comprises a series of runs as determined by the DOE in which purposeful changes are made to the input variables. Minitab17 is utilized to aid in the analysis and presentation of the experimental data.

A response data methodology is used to determine the effects of the four variable process parameters on the mass yield (on a dry, ash-free basis), energy density, energy yield of torrefied Cogon grass, as well as the effects of the reaction time and RT on the mass yield and energy density of the condensate.

The mass yield on a dry, ash-free basis $\left(\mathrm{MY}_{\mathrm{daf}}\right)$ measures the fraction of the original organic component of biomass that is converted into solid char and is computed using the formula shown below [6]:

$$
M Y_{d a f}=\left[M Y_{d b}-A S H(\%)_{d b}\right] \div\left[1-A S H(\%)_{d b}\right],
$$

where $\operatorname{ASH}(\%)_{\mathrm{db}}=$ ash content of torrefied biomass on a dry, ash-free basis

$\mathrm{MY}_{\mathrm{db}}=$ mass yield of torrefied biomass

$\mathrm{MY}_{\mathrm{db}}=$ mass of torrefied biomass $\div$ [mass of original biomass $\div(1-\mathrm{M})$ ]

$\mathrm{MY}_{\mathrm{ar}}=\mathrm{MY}_{\mathrm{db}} \times\left[1-\mathrm{M}(\%)_{\mathrm{arT}}\right]=$ mass yield on an as-received-basis

$\mathrm{M}=$ moisture content of the as-received untorrefied biomass

$\mathrm{M}(\%)_{\mathrm{ar}}=$ moisture content of the torrefied biomass

The energy density measures the amount of energy released by the unit mass or volume of the torrefied product once it is combusted or burned and its product is cooled. It is also defined as an equivalent to the HHV or lower heating value, which can be expressed in terms of its as-received, dry, and dry, ash-free basis. The energy density of the torrefied product is computed using the formula shown below [6]:

$$
H H V_{d a f}=H H V_{d b} \div\left[1-A S H(\%)_{d b}\right]
$$


where $\mathrm{HHV}_{\mathrm{ar}}=\mathrm{HHV}$ as measured in a bomb calorimeter

$\mathrm{HHV}_{\mathrm{db}}=\mathrm{HHV}$ on a moisture-free basis $=\mathrm{HHV}_{\mathrm{ar}} \div\left[1-\mathrm{M}(\%)_{\mathrm{ar}}\right]$

$\mathrm{HHV}_{\mathrm{daf}}=\mathrm{HHV}$ on dry, ash-free basis

$\mathrm{M}(\%)_{\mathrm{ar}}=$ moisture content of biomass on a as-received basis

$\mathrm{ASH}(\%)_{\mathrm{db}}=$ ash content on a dry basis

The energy yield (EY) measures the amount of energy-rich components remaining in the biomass after it was torrefied. The torrefaction process leads to some loss in the overall energy content of the biomass although there is an increase in the energy density on the torrefied biomass. The EY quantitatively measures the value of this loss and is defined using the formula shown below:

$$
\mathrm{EY}=\text { Energy in torrefied product } \div \text { Energy in raw biomass. }
$$

EY can be expressed in terms of $\mathrm{MY}_{\mathrm{daf}}$ and is defined using the shown presented below:

$$
\mathrm{EY}_{\mathrm{daf}}=\mathrm{MY}_{\mathrm{daf}}\left(\mathrm{HHV}_{\mathrm{daf}} \text { of product } \div \mathrm{HHV}_{\mathrm{daf}} \text { of feed }\right) \text {. }
$$

The mass yield of the condensate $\left(\mathrm{MY}_{\mathrm{C}}\right)$ and energy density of the condensate $\left(\mathrm{HHV}_{\mathrm{ar}-\mathrm{c}}\right)$ is determined using the formula shown below:

$\mathrm{MY}_{\mathrm{C}}=\left(\right.$ Volume of evolved condensate $\left.\times \boldsymbol{\rho}_{\mathrm{c}}\right) \div$ Mass of biomass feed on an ash-free basis,

where $\mathrm{HHV}_{\mathrm{ar}-\mathrm{c}}=\mathrm{HHV}$ as measured in a bomb calorimeter.

The fuel qualities are measured in terms of the fuel and elemental ratios. The fuel ratio refers to the ratio of fixed carbon content (wt\%) to the volatile matter content (wt\%). The elemental ratio refers to the ratio of oxygen $(\mathrm{O})$ and hydrogen $(\mathrm{H})$ to carbon $(\mathrm{C})$, which are expressed as $\mathrm{O} / \mathrm{C}$ and $\mathrm{H} / \mathrm{C}$, respectively. From an energy density prospective, the energy contained in a $\mathrm{C}-\mathrm{C}$ bond is higher than that in $\mathrm{C}-\mathrm{O}$ or $\mathrm{C}$ $\mathrm{H}$ bonds [17]. A relative increase in the $\mathrm{C}$ content in the fuel indicates better combustion characteristics as it directly results in a higher energy density. Fuels with lower $\mathrm{O} / \mathrm{C}$ and $\mathrm{H} / \mathrm{C}$ ratios display lower energy losses due to the reduction of over-oxidation of the fuel, smoke, and water vapor [9][11][18].

\section{Materials and Methods}

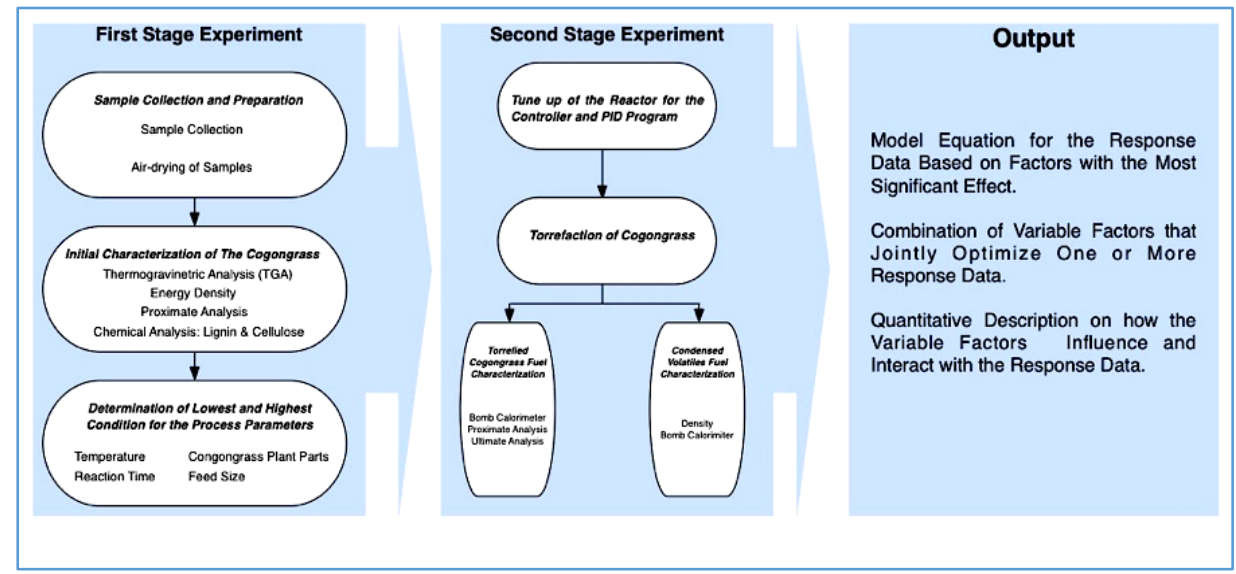

Fig. 1. Flowchart of the methodology

This study determines the effects of the RT, reaction time, feed size, and plant parts on torrefied Cogon grass and the RT and reaction time to condensable organic volatile products of the torrefaction process using a fabricated wall-particle conduction batch torrefaction reactor. The activities involved in the second stage of the experiment are as follows: (1) sample collection and preparation, (2) initial 
characterization of the untreated air-dried Cogon grass, (3) tune-up of the reactor, (4) torrefaction process, (5) analysis of physical and fuel properties of the torrefied Cogon grass, and (6) analysis of the fuel properties of the condensate. The method adopted in this research is summarized as a flowchart in Fig.1.

Cogon grass is collected in early February 2014 and January 2016 in Barangay Tiniguiban, Puerto Princesa City, Palawan. The samples are prepared by air drying for about one to two weeks. The samples collected in 2014 are cut into various lengths to determine the appropriate lengths to be considered in the torrefaction process of Cogon grass. After the longest and shortest lengths are determined in the pre-trial, the samples collected in January 2016 are cut based on the sizes determined in the initial trial run. The samples are then stored under ambient conditions in preparation for thermal upgrading.

To establish the thermal properties of the sun-dried Cogon grass, the temperatures associated with the hemicellulose degradation, the peak of hemicellulose degradation, and the point of its maximum devolatilization of Cogon grass at different heating temperatures are determined using a TA-Instrument Q-50 thermogravimetric analysis system. The results of this analysis will also determine the minimum and maximum temperatures required in the torrefaction process to yield the desired upgraded biofuel.

An adiabatic oxygen bomb calorimeter (Par1356 Isoperibol Bomb Calorimeter) is used to determine the heating value of the air-dried, torrefied Cogon grass and condensed gases.

The moisture and ash contents of the samples are determined using methods 925.45B and 923.03, respectively, in accordance to the Official Method of Analysis of the Association of the Official analytical chemist (A.O.A.C.) 17th ed., 2002. The volatile matter is determined by subtracting the sum of Fixed carbon $(\mathrm{FC})(\%)_{\mathrm{db}}$ and $\mathrm{ASH}(\%)_{\mathrm{db}}$ to $100 \%$. FC is determined by deriving the $\mathrm{FC}(\%)_{\mathrm{ar}}$ using the Demibras (1997) equation model of biomass fuel. Demibras proposed a correlation of the biomass $\mathrm{HHV}_{\mathrm{ar}}$ $(\mathrm{MJ} / \mathrm{kg})$ as a function of its FC (wt.\%). The Demibras (1997) equation model of biomass fuel HHV is shown below [19]:

$$
H H V_{a r}=0.196\left(F C_{a r}\right)+14.119(M J / k g),
$$

Chemical analysis of lignin, holocellulose, alpha-cellulose, and hemicellulose is performed at the Fiber Processing and Utilization Laboratory of the Philippine Fiber Industry Development Laboratory located at Visayas Avenue, Quezon City.

Elemental analysis of the samples is determined using the Nhuchlen (2016) correlation equation of volatile matter $(\mathrm{VM})$; FC; and ash with carbon $(\mathrm{C})$, hydrogen $(\mathrm{H})$, and oxygen $(\mathrm{O})$. This equation can be used to predict the $\mathrm{C}, \mathrm{H}$, and $\mathrm{O}$ composition of the raw and torrefied biomass as concluded by $\mathrm{D}$. R. Nhuchhen in 2016, particularly for biomass that has negligible nitrogen and sulfur contents. The following equations are adopted in this study to determine the sample's elemental composition $(\mathrm{C}, \mathrm{H}$, and O) [17]:

$$
\begin{aligned}
& \mathrm{C}=-35.9972+0.7698 \mathrm{VM}+1.3269 \mathrm{FC}+0.3250 \mathrm{ASH} \\
& \mathrm{H}=55.3678-0.4830 \mathrm{VM}-0.5319 \mathrm{FC}+0.5600 \mathrm{ASH} \\
& \mathrm{O}=223.6805-1.7226 \mathrm{VM}-2.2296 \mathrm{FC}+2.2463 \mathrm{ASH}
\end{aligned}
$$

A 2-mL Guy-Lussac-type glass pycnometer with a volume accuracy of $0.001 \mathrm{~cm}^{3}$ is used to determine the density of the condensed gas samples from each of the torrefaction runs.

A stainless steel fabricated wall-particle conduction batch torrefaction reactor heated externally using an electric heating element controlled by a PID controller is used in the torrefaction process of Cogon grass. A thermocouple is inserted into the reactor to automatically control the heat generated by the electric heating element using a PID controller. The torrefaction conditions are determined (highest and lowest) based on the results of the 1st stage experiment. The condensable gases generated during torrefaction are collected using a sterilized $50-\mathrm{mL}$ centrifugal plastic tubes connected to a copper tube 
with a copper coil condenser cooled using water maintained at ambient temperature. A schematic of the experimental set-up is shown in Fig. 2.

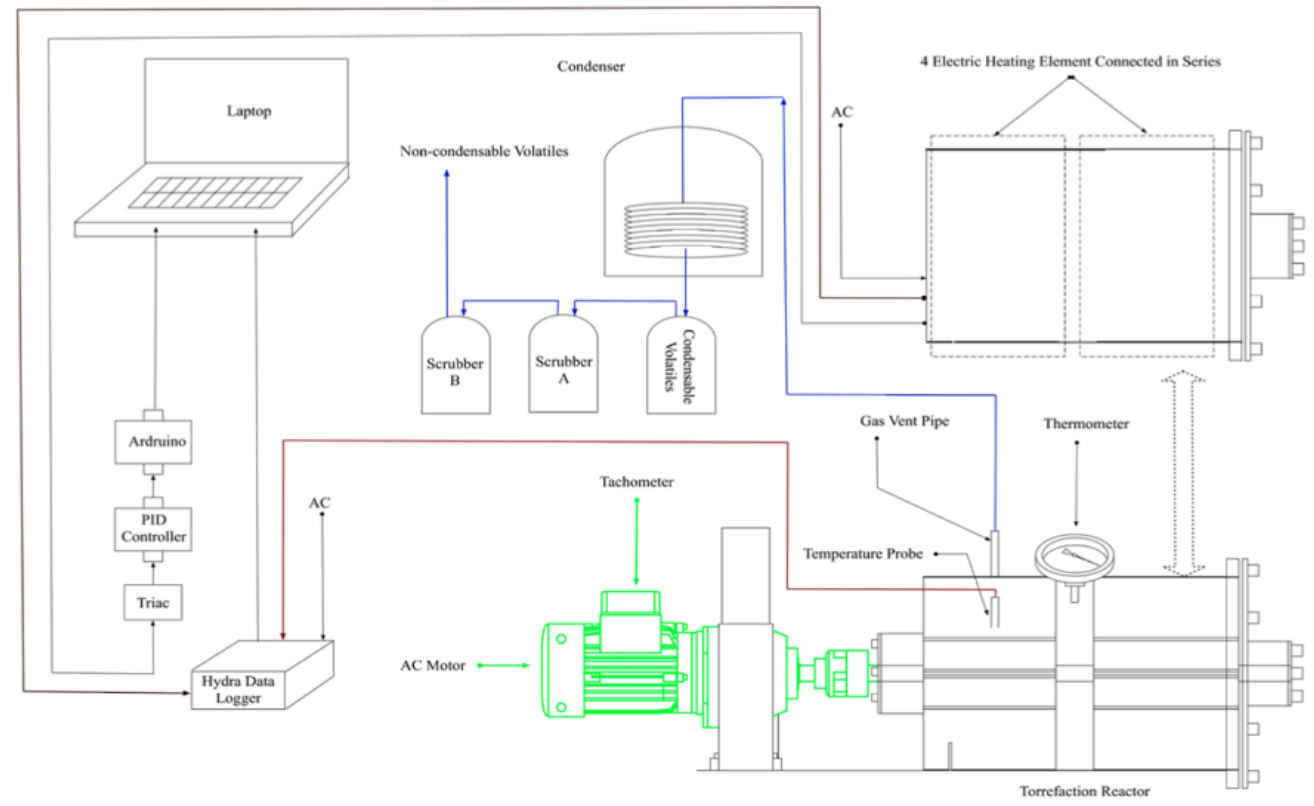

Fig. 2. Schematic of the experimental set-up

\section{Results and Discussion}

\subsection{Fuel characteristics of the sun-dried Cogon grass}

The thermogravimetric analysis (TGA) curves obtained for the sun-dried Cogon grass leaves and nodes are shown in Fig. 3. The TGA curve also shows the burning process of Cogon grass with distinct sub-processes labeled from 1 to 5 . Sub-process 1 shows the initial decrease in weight attributed to moisture loss. Sub-process 2 reflects the thermal decomposition of the lignocellulosic components of Cogon grass. Sub-process 3 shows the weight loss due to combustion. Oxygen gas is introduced, whereas nitrogen gas is flushed out at the start of sub-process 3. Sub-process 4 shows the combustion of carbon, and sub-process 5 is the ash formation step, which occurs at a high temperature.

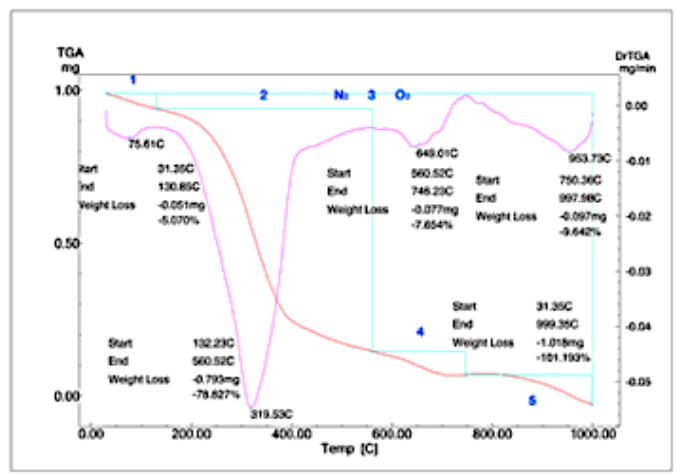

(a)

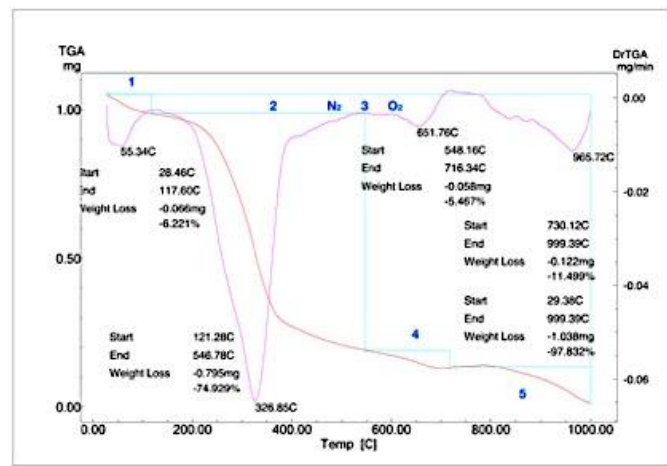

(b)

Fig. 3. Thermogravimetric analysis of the sun-dried Cogon grass (a) nodes and (b) leaves

The sun-dried Cogon grass nodes used in this study contains $32.31 \%$ hemicellulose, $52.91 \%$ alphacellulose, $82.47 \%$ holocellulose, and $17.31 \%$ lignin. While the sun-dried Cogon grass leaves used in this 
study contains $24.84 \%$ hemicellulose, $40.37 \%$ alpha-cellulose, $77.76 \%$ holocellulose, and $14.11 \%$ lignin. The initial mass loss corresponds to moisture loss. The second mass loss is the moisture loss from chemically bound water, which extends up to $225^{\circ} \mathrm{C}$ [20], and beyond this temperature is the initial degradation of hemicellulose. Hemicellulose continues to degrade up to $274.89^{\circ} \mathrm{C}$, and cellulose starts to degrade at $275^{\circ} \mathrm{C}$ [20]. The thermal degradation of lignin is relatively insensitive to torrefaction, regardless of temperature [20]. Based on the TGA, an estimated $74 \%$ mass yield can be expected from both nodes and leaves if the torrefaction RT is set to $275^{\circ} \mathrm{C}$ (degrading only the hemicellulose).

The heating value and proximate analysis of the sun-dried Cogon grass leaves and nodes are listed in Table 1.

Table 1. Fuel properties of the sun-dried Cogon grass leaves and nodes

\begin{tabular}{lll}
\hline Fuel Properties & Leaves & Nodes \\
\hline $\mathrm{HHV}_{\mathrm{ar}}(\mathrm{kJ} / \mathrm{kg})$ & $14,175.65$ & $14,556.48$ \\
$\mathrm{HHV}_{\mathrm{db}}(\mathrm{kJ} / \mathrm{kg})$ & $15,854.66$ & $16,392.43$ \\
$\mathrm{HHV}$ & $18,416.38$ & $17,641.44$ \\
$\mathrm{M}(\%)_{\mathrm{ar}}(\mathrm{kJ} / \mathrm{kg})$ & $10.59 \%$ & $11.2 \%$ \\
$\mathrm{ASH}(\%)_{\mathrm{db}}$ & $13.91 \%$ & $7.08 \%$ \\
$\mathrm{FC}(\%)_{\mathrm{db}}$ & $0.32 \%$ & $2.51 \%$ \\
$\mathrm{VM}(\%)_{\mathrm{db}}$ & $85.77 \%$ & $90.41 \%$ \\
\hline
\end{tabular}

Cogon grass nodes exhibit a higher energy density on the as-received basis $\left(\mathrm{HHV}_{\mathrm{ar}}\right)$ compared to that of the leaves because its FC (\%) to VM (\%) ratio is seven times higher than that of Cogon grass leaves. The high lignin content of the Cogon grass nodes also contributes to its high energy density because lignin contains more $\mathrm{C}-\mathrm{C}$ bonds. Lignin, based on its structural characterization, is linked by a multitude of inter-unit bonds that include several types of ether and carbon-carbon linkages [21]. This is further validated by the elemental composition of both Cogon grass leaves and nodes, where the nodes (39.23\%) contain a higher $\mathrm{C}$ content than that of the leaves $(34.9757 \%)$. However, on a dry, ash-free basis $\left(\mathrm{HHV}_{\mathrm{daf}}\right)$, the Cogon grass nodes exhibit a low energy density. However, based on the proximate analysis using the TGA data (see Table 2), the Cogon grass leaves exhibit a high energy density based on the computed $\mathrm{HHV}_{\text {daf }}$ using the Demibras equation. The difference in the $\mathrm{M}(\%)$ obtained using the traditional approach to the $\mathrm{M}(\%)$ obtained using the TGA data is caused by the temperature reference point used to calculate the $\mathrm{M}(\%)$. The traditional $\mathrm{M}(\%)$ determination uses the A.O.A.C. method $925.45 \mathrm{~B}$, where $\mathrm{M}(\%)$ is determined according to mass loss after drying the sample at a temperature of $105^{\circ} \mathrm{C}$. In the TGA method, the temperature reference used to calculate $\mathrm{M}(\%)$ is based on the mass loss of the sample before its oxidation [22][23][24]. The consistent high energy density (ar, db, and daf basis) of the sun-dried Cogon grass leaves is attributed to its high FC/VM ratio, which is 1.24 times higher than that of the nodes.

Table 2. Computed HHV based on the FC (\%) and M (\%) obtained from the TGA data

\begin{tabular}{llll}
\hline Cogon grass parts & $\mathrm{HHV}_{\mathrm{ar}}(\mathrm{kJ} / \mathrm{kg})$ computed & $\mathrm{HHV}_{\mathrm{db}}(\mathrm{kJ} / \mathrm{kg})$ computed & $\mathrm{HHV}_{\mathrm{daf}}(\mathrm{kJ} / \mathrm{kg})$ computed \\
\hline Leaves & $15,208.42$ & $16,217.30$ & $18,786.77$ \\
Nodes & $15,178.93$ & $15,989.61$ & $17,454.57$ \\
\hline
\end{tabular}

A disadvantage of the sun-dried Cogon grass nodes over the leaves is that its $\mathrm{M}(\%)$ is high. M (\%) influences the combustion behavior of the solid fuel. Wet solid fuels require a long residence time for drying before gasification or combustion can occur, which means it requires a larger combustion chamber [25]. In addition, the efficiency of the combustion system (heat output of the boiler/energy input by the fuel) decreases as the moisture content of the fuel increases [25].

The ash content of solid fuel also influences its thermal utilization [25]. Higher ash content in the fuel usually leads to higher dust emissions and has an influence on the heat exchanger design, heat exchanger cleaning system, and dust precipitation technology [25]. Si, $\mathrm{Ca}, \mathrm{Mg}, \mathrm{K}, \mathrm{Na}$, and $\mathrm{P}$ are the major ashforming elements that occur in biomass fuels [25] although Cogon grass contains a low concentration of Si $(2.9 \pm 0.1 \mathrm{wt} \%)$ [26]. Sun-dried Cogon grass nodes have a lower ASH (\%) than that of the sun-dried Cogon grass leaves. 


\subsection{Energy density, mass yield, and EY of torrefied Cogon grass}

Analysis of the factorial design indicates that the RT is the only parameter that has a significant effect on the increase in the energy density $\left(\mathrm{HHV}_{\mathrm{daf}}\right)$ of the torrefied Cogon grass leaves and nodes. The RT has an estimated standardized effect of 2.145 to the increase in energy density of the torrefied Cogon grass leaves and nodes. The overall effect of the increase in the RT $\left(250^{\circ} \mathrm{C}-285^{\circ} \mathrm{C}\right)$ is an increase in the $\mathrm{HHV}_{\text {daf }}$ from a mean value of $23.0287-25.3068 \mathrm{MJ} / \mathrm{kg}$.

The Cogon grass parts (CPs) as a parameter exhibit the greatest effect on the mass and EY of the torrefied Cogon grass. However, it can also be seen that RT and time have significant effects on both, whereas the feed size affects only the $\mathrm{EY}_{\text {daf. }}$ This is shown in Fig. $4 \mathrm{a}-\mathrm{c}$, which present the response surface plots of the mass and EYs of the torrefied samples as a function of the RT and reaction time with the $\mathrm{CP}$ as the holding value.

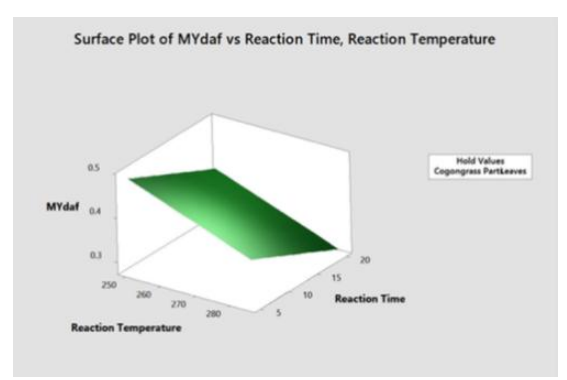

(a)

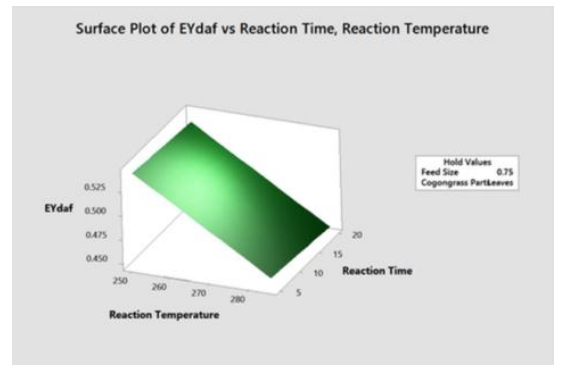

(c)

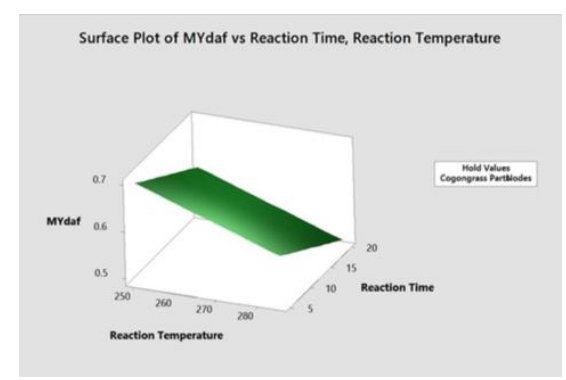

(b)

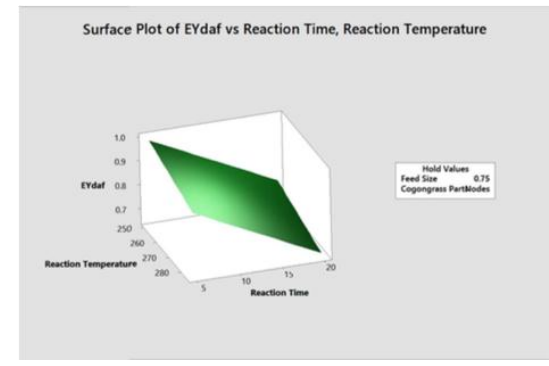

(d)

Fig. 4. Response surface plots for $\mathrm{MY}_{\text {daf }}$ (a) and (b) and $\mathrm{EY}_{\text {daf }}$ (c) and (d).

From Fig. 3, the main effect of $\mathrm{CP}$ on $\mathrm{MY}_{\text {daf }}$ is it increases from $38.62 \%$ to $59.84 \%$ if the feed is shifted from leaves to nodes. This is due to the high lignin content of the nodes wherein it takes a higher RT and longer reaction time to torrify the Cogon grass nodes. Over the temperature range of $250^{\circ} \mathrm{C}-$ $285^{\circ} \mathrm{C}$, the $\mathrm{MY}_{\text {daf }}$ decreases its mean value from $54.58 \%$ to $43.88 \%$. The $\mathrm{EY}_{\text {daf }}$ also shows a decrease in its mean value from $70.30 \%$ to $61.60 \%$. This is due to the large increase in the energy density $(23.0287$ $\mathrm{MJ} / \mathrm{kg}$ at $250^{\circ} \mathrm{C}$ and $25.3068 \mathrm{MJ} / \mathrm{kg}$ at $285^{\circ} \mathrm{C}$ ) of the torrefied Cogon grass upon increasing the RT, which off-sets the large decrease in the mass yield. The maximum decrease in $\mathrm{MY}_{\text {daf }}$ and $\mathrm{EY}_{\text {daf }}$ are significantly affected by the RT, reaction time (Rt), and CP.

As described in the response surface models in Table 3, $\mathrm{MY}_{\mathrm{daf}}$ and $\mathrm{EY}_{\mathrm{daf}}$ are significantly affected by the RT, Rt, and CP. An interaction between the RT and CP also significantly affects the EY daf of torrefied Cogon grass. The energy density of the torrefied Cogon grass is only dependent on the RT of the torrefaction process.

The mean mass yield for the leaves and nodes is $38.62 \%$ and $59.84 \%$, respectively, from an initial feed of $370 \mathrm{~g}$ of sun-dried Cogon grass leaves or nodes. The mean EY for the torrefied Cogon grass leaves and nodes is $49.62 \%$ and $82.28 \%$, respectively. 
Table 3. Response surface models of the torrefied solid products of Cogon grass

\begin{tabular}{lllll}
\hline Response & \multicolumn{1}{c}{ Variables } & $\mathbf{R}_{\text {adj }}$ & $\mathbf{R}_{\text {pred }}$ \\
\hline $\mathrm{HHV}_{\text {daf }}(\mathrm{MJ} / \mathrm{kg})$ & $6.76+0.0651 \mathbf{R T}$ & 0.30 & 0.15 \\
$\mathrm{MY}_{\text {daf }}(\%)$ & $1.39-0.003056 \mathbf{R T}-0.0064 \mathbf{R t}+0.1061 \mathbf{C P}$ & 0.79 & 0.70 \\
$\mathrm{EY}_{\text {daf }}(\%)$ & $1.539-0.002487 \mathbf{R T}-0.1422 \mathbf{F Z}-0.00859 \mathbf{R t}+0.2651 \mathbf{C P}+0.95$ & 0.91 \\
\hline
\end{tabular}

\subsection{Mass yield and energy density of the condensates}

The mass yield $\left(\mathrm{MY}_{\mathrm{c}}\right)$ of the condensates increases upon increasing the reaction time. The reaction time range of 5-20 min has a standardized effect of 2.5 on the increase in the $\mathrm{MY}_{\mathrm{c}}$ from $11.06 \%$ to 12.18\%. This is shown on Table 4, which presents the $\mathrm{MY}_{\mathrm{c}}$ response surface model of the torrefied Cogon grass condensate mass yield is significantly affected by the Rt. The increase in the condensate mass yield is due to the increased thermal degradation of the lignocellulosic components upon prolonging the reaction time.

Table 4. Response surface models of the torrefied solid products of Cogon grass.

\begin{tabular}{llll}
\hline Response & \multicolumn{1}{c}{ Variables } & $\mathbf{R}_{\text {adj }}$ & $\mathbf{R}_{\text {pred }}^{2}$ \\
\hline $\mathrm{HHV}_{\mathrm{ar}-\mathrm{c}}(\mathrm{MJ} / \mathrm{kg})$ & $18.6470+1.193 \mathbf{R T}+0.324 \mathbf{F Z}-1.1860 \mathbf{C P}+0.6170(\mathbf{R T})(\mathbf{C P})+$ & 0.94 & 0.89 \\
& $0.4720(\mathbf{F Z})(\mathbf{R t})(\mathbf{C P})$ & & \\
$\mathrm{MY}_{\mathrm{c}}(\%)$ & $0.01069+0.00075 \mathbf{R t}$ & 0.32 & 0.17 \\
\hline
\end{tabular}

The energy density of the organic condensate samples increases upon increasing the RT and as the feed is shifted from leaves to nodes. This is shown in Fig. 5, which presents the energy density of the organic condensate $\left(\mathrm{HHV}_{\mathrm{ar}-\mathrm{c}}\right)$ as a function of the feed size with the $\mathrm{CP}$ as hold values of either leaves or nodes. The RT of $250^{\circ} \mathrm{C}-285{ }^{\circ} \mathrm{C}$ has a standardized effect of 9 on the increase in the mean $\mathrm{HHV}_{\mathrm{arc}}$ from 17.4538 to $19.8406 \mathrm{MJ} / \mathrm{kg}$. The highest increase in the $\mathrm{HHV}_{\text {ar-c }}$ occurs at $285^{\circ} \mathrm{C}$ with a feed size of 0.5 inch in the length of leaves having a reaction time of 5 min. Fig. 6 summarizes the energy density of the organic condensates under the various torrefaction conditions that have a significant effect toward increasing $\mathrm{HHV}_{\mathrm{ar}-\mathrm{c}}$.

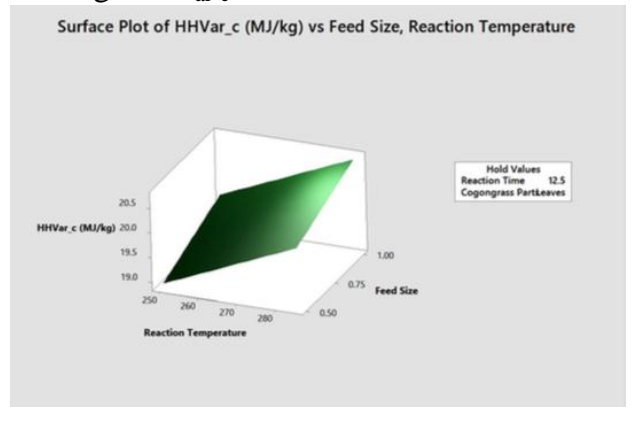

(a)

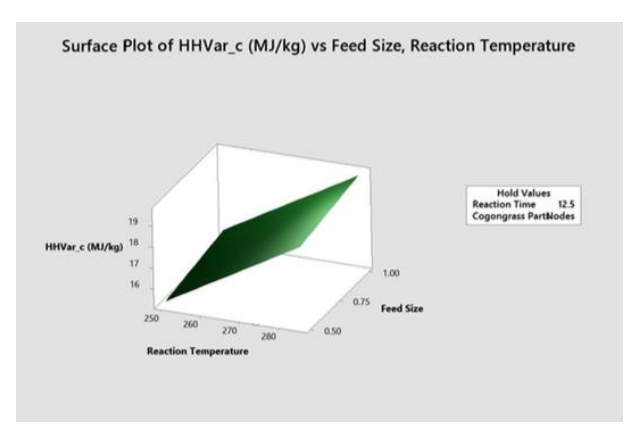

(b)

Fig. 5. Response surface plots of $\mathrm{HHV}_{\mathrm{ar}-\mathrm{c}}$ for (a) leaves and (b) nodes

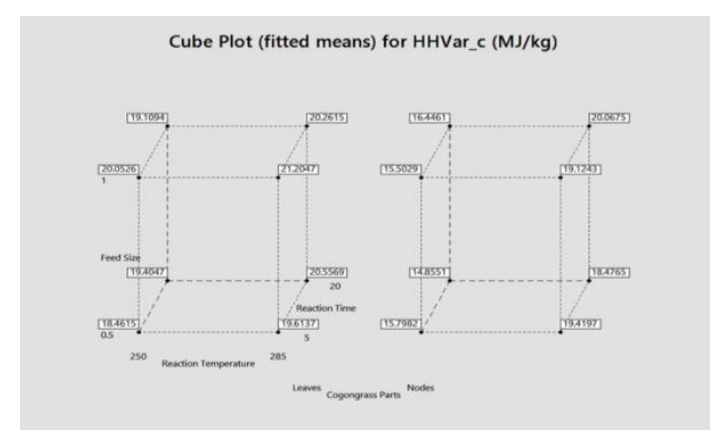

Fig. 6. Cube plot of $\mathrm{HHV}_{\mathrm{ar}-\mathrm{c}}$. 


\subsection{Fuel characteristics of torrefied Cogon grass}

Torrefied Cogon grass has a higher energy density and FC/VM with a low H/C and O/C ratio compared to that of the sun-dried Cogon grass. The increase in the energy density of the torrefied Cogon grass leaves and nodes is attributed to the decrease in the $\mathrm{H}$ and $\mathrm{O}$ content of the torrefied Cogon grass. The FTIR analysis of the condensed organic volatiles of the torrefied Cogon grass leaves and nodes reflects the high absorption of the hydroxyl groups, which may indicate a low $\mathrm{O}$ and $\mathrm{H}$ content in the solid product of torrefied Cogon grass. The moisture content of the torrefied Cogon grass nodes increases from $11.2 \%$ (sun-dried) to $15.73 \%$ due to moisture absorbance during storage and transport for analysis, suggesting that the torrefied Cogon grass nodes may have high hydroxyl content compared to that of the leaves. Based on the summary of the fuel characteristics in Table 5, Cogon grass leaves are an ideal feed for the torrefaction of Cogon grass because its torrefied solid products have better fuel properties and it is thermally sensitive to the torrefaction temperature $\left(250^{\circ} \mathrm{C}-285^{\circ} \mathrm{C}\right)$ compared to the Cogon grass nodes. This may be attributed to the high lignin content of the Cogon grass nodes resulting in a relatively low mass loss. It is further observed that an increase in the ash content of the torrefied solid product is mainly due to the mass loss (concentration effect) during the torrefaction reaction.

Table 5. Fuel properties of torrefied Cogon grass

\begin{tabular}{lcccc}
\hline \multicolumn{1}{c}{ Fuel properties } & Torrefied leaves & Torrefied nodes & \multicolumn{2}{c}{ Sub-bituminous coal [39] } \\
Heating value $(\mathrm{MJ} / \mathrm{kg})$ & Class \\
\hline $\mathrm{HHV}_{\mathrm{ar}}(\mathrm{MJ} / \mathrm{kg})$ & 17.88 & 18.02 & \\
$\mathrm{HHV}_{\mathrm{db}}(\mathrm{MJ} / \mathrm{kg})$ & 18.87 & 21.45 & $\geqslant 22.09 \mathrm{HHV}_{\mathrm{daf}}<24.418$ & $\mathrm{~B}$ \\
$\mathrm{HHV}_{\mathrm{daf}}(\mathrm{MJ} / \mathrm{kg})$ & 23.95 & 24.39 & $\geqslant 19.30 \mathrm{HHV}_{\mathrm{daf}}<22.09$ & $\mathrm{C}$ \\
& & & \\
$\mathrm{M}(\%)_{\mathrm{ar}}$ & $5.275 \%$ & $15.76 \%$ & \\
$\mathrm{ASH}(\%)_{\mathrm{db}}$ & $21.02 \%$ & $11.93 \%$ & \\
$\mathrm{FC}(\%)_{\mathrm{db}} / \mathrm{VM}(\%)_{\mathrm{db}}$ & 0.3627 & 0.3794 & \\
$\mathrm{H} / \mathrm{C}$ & 0.1046 & 0.1036 & \\
$\mathrm{O} / \mathrm{C}$ & 0.7086 & 0.1036 & \\
\hline
\end{tabular}

Based on the ASTM Classification (D388-15) of coals, the torrefied Cogon grass leaves and nodes are comparable to sub-bituminous class $\mathrm{B}$ and $\mathrm{C}$ coals where the heating value for this rank of coal ranges from 19 to $24 \mathrm{MJ} / \mathrm{kg}$ on a dry, ash-free basis [27].

\subsection{Summary of findings}

The sun-dried Cogon grass nodes contain $32.31 \%$ hemicellulose, $52.91 \%$ alpha-cellulose, $82.47 \%$ holocellulose, and $17.31 \%$ lignin. While the sun-dried Cogon grass leaves contain $24.84 \%$ hemicellulose, $40.37 \%$ alpha-cellulose, $77.76 \%$ holocellulose, and $14.11 \%$ lignin. The Cogon grass leaves are deemed to be the better plant part for torrefaction due to the thermal insensitivity of the Cogon grass nodes to the torrefaction process. The condensed organic gases at a RT of $250^{\circ} \mathrm{C}$ and $285^{\circ} \mathrm{C}$ have a heating value of 23.03 and $25.31 \mathrm{MJ} / \mathrm{kg}$, respectively. Table 6 shows the fuel characteristics of the sun-dried and torrefied Cogon grass.

Table 6. The Fuel characteristics of Cogon grass

\begin{tabular}{lllll}
\hline \multirow{2}{*}{ Fuel properties } & \multicolumn{2}{c}{ Sun-dried } & \multicolumn{2}{c}{ Torrefied } \\
& Leaves & Nodes & Leaves & Nodes \\
\hline $\mathrm{HHV}_{\mathrm{db}}(\mathrm{MJ} / \mathrm{kg})$ & 15.85 & 16.39 & 18.87 & 21.45 \\
$\mathrm{HHV}_{\mathrm{daf}}(\mathrm{MJ} / \mathrm{kg})$ & 18.42 & 17.64 & 23.95 & $15.76 \%$ \\
$\mathrm{M}(\%)_{\mathrm{ar}}$ & $10.59 \%$ & $11.2 \%$ & $5.275 \%$ & $11.93 \%$ \\
$\mathrm{ASH}(\%)_{\mathrm{db}}$ & $13.91 \%$ & $7.08 \%$ & $21.02 \%$ & 0.3794 \\
$\mathrm{FC}(\%)_{\mathrm{db}} / \mathrm{VM}(\%)_{\mathrm{db}}$ & 0.0038 & 0.0278 & 0.3627 & 0.1036 \\
$\mathrm{H} / \mathrm{C}$ & 0.1710 & 0.1631 & 0.1046 & 0.1036 \\
$\mathrm{O} / \mathrm{C}$ & 1.2572 & 1.1836 & 0.7086 & \\
\hline
\end{tabular}




\section{Conclusions and Recommendations}

A torrefaction process was successfully used to upgrade the fuel properties of sun-dried Cogon grass leaves and nodes. Based on the determined fuel characteristics of the solid products, torrefied Cogon grass had a higher energy density and FC/VM with a low $\mathrm{H} / \mathrm{C}$ and $\mathrm{O} / \mathrm{C}$ ratio compared to that of sundried Cogon grass. It was also determined that the energy density of the condensed gases was comparable to the energy density of the sun-dried Cogon grass leaves and nodes, which has promising potential as a biocrude fuel.

For the range of variable parameters considered, an increased RT significantly increased the energy density of the torrefied solid products. Torrefaction improved the energy density on a dry, ash-free basis from 18.42 to $23.95 \mathrm{MJ} / \mathrm{kg}$ for the Cogon grass leaves and from 17.64 to $24.39 \mathrm{MJ} / \mathrm{kg}$ for the Cogon grass nodes. This is because at a high RT, the hemicellulose effectively degraded and the cellulose partially degraded. In turn, this significantly reduced the oxygen content and partially removed the volatile content of the solid product. The resulting solid biofuel was comparable to class B and C sub-bituminous coals. The mean mass yields of the torrefied Cogon grass leaves and nodes were $38.62 \%$ and $59.84 \%$, respectively. Although the torrefied Cogon grass mass yield on a dry, ash-free basis was low, it was compensated by the mean increase of $34 \%$ of its energy density. The energy density of the torrefied Cogon grass was only dependent on the RT of the torrefaction process.

The shift in the type of feed from Cogon grass leaves to Cogon grass nodes significantly affected the increase in the MY and EY of the torrefied Cogon grass solid products. The higher lignin content of the Cogon grass nodes rendered it relatively thermally insensitive to torrefaction in the RT range of $250^{\circ} \mathrm{C}-$ $285^{\circ} \mathrm{C}$. Hence, the leaves were deemed to be a better plant part for torrefaction. Moreover, the RT, feed size, reaction time, and feed parts had significant effects and may be used to predict the $\mathrm{MY}_{\mathrm{daf}}$ and $\mathrm{EY}_{\mathrm{daf}}$ of the torrefied Cogon grass using the response surface model for $\mathrm{MY}_{\mathrm{daf}}$ and $\mathrm{EY}_{\text {daf }}$. This may provide a convenient method to estimate the mass of the torrefied solid product as well as the expected energy retained from the torrefaction of Cogon grass. However, the model was not validated at intermediate points and was based on only two levels per parameter.

The energy density of the organic condensate products of torrefied Cogon grass increased from 17.45 to $19.84 \mathrm{MJ} / \mathrm{kg}$ as the RT increased from $250^{\circ} \mathrm{C}$ to $285^{\circ} \mathrm{C}$. A similar effect was also observed as the feed was shifted from Cogon grass nodes to leaves. The surface response model for the energy density of the condensed organic products of the torrefied Cogon grass may be used to predict its energy density. The model had an adjusted coefficient of multiple correlation $\left(\mathrm{R}_{\text {adj }}^{2}\right)$ value of 0.94 . The model was not validated at intermediate points and was based on only two levels per parameter.

A wider range for the RT and reaction time as the variable process parameters must be studied to determine the optimum conditions for the thermal upgrading of Cogon grass as a biocoal. The cooling time should also be investigated to discover if it has a significant effect on the fuel properties of both the solid and biocrude products of torrefaction.

Further evaluation using different endemic biomass from the Philippines will provide a better range of suitable feedstocks for the torrefaction process considering plastic wastes mixed with biomass is a good alternative feedstock for the torrefaction process.

Further chemical analysis of the condensed organic volatiles is recommended to specifically identify its composition to obtain a detailed fuel characterization and explore its potential as a biocrude fuel.

\section{Acknowledgements}

I would like to express my sincere gratitude to my adviser Dr. Rizalinda L. De Leon for the continuous support of my MS study and research. Her expertise in the field and for her patience, motivation, enthusiasm, and immense knowledge are much appreciated. Her guidance helped me a lot with the research and writing of this thesis.

Thank you for the panel members for their valuable comments and suggestions during the oral defense.

I would like thank my mother, Carmencita Garcia Palanca, for all the financial assistance and 
encouragement that helped me finished with my studies and experiments on time. I would like to extend my gratitude to University of the Philippines Sustainable Energy Program (UP SEP) for the financial support though my salary as a research assistant of UP SEP.

To Jocelyn Villacentino, thank you so much.

To my FETs laboratory mates, thank you for your support and assistance during my thesis laboratory work.

To God be the glory!

\section{References}

[1] World Bank. (2014). Philippine Economic Update: Investing in the Future Sharing Growth and Job Opportunities for All. Retrieved from www.worldbank.org.ph

[2] Crastan V. (2014). Global Energy Demand and 2-degree Target, Report 2014. Springer International Publishing.

[3] OPEC. (2015). OPEC Annual Statistical Bulletin. Vienna, Austria. Retrieved from www.opec.org

[4] Batidzirai B, Mignot APR, Schakel WB, Junginger H.M, and Faaij APC, "Biomass torrefaction technology: Technoeconomic status and future prospects," Energy, 62: 196-214, 2013.

[5] Edenhofer O and Pichs-Madruga R, IPCC, Special report on renewable energy sources and climate change mitigation. Michael Melford/National Geographic Stock, 2011.

[6] Basu P, Biomass Gasification and Pyrolysis (practical design and Theory, Burlington, USA: Elsevier Inc., 2010.

[7] Van der Stelt MJC, Gerhauser H, Kiel JHA, and Ptasinski KJ, Biomass upgrading by torrefaction for the production of biofuels: A review. Biomass and Bioenergy, 35(9): 3748-3762, 2011.

[8] Koppejan SSJ, Staffan M, and Sebnem M, Status overview of torrefaction technologies, 2012.

[9] Prins MJ, Ptasinski KJ, and Janssen FJJG. More efficient biomass gasification via torrefaction. Energy, 31: 3458-3470, 2006

[10] Prins, MJ, Ptasinski, KJ, \& Janssen, FJJG. (2006). Torrefaction of wood. Part 2. Analysis of products. Journal of Analytical and Applied Pyrolysis, 77:35-40.

[11] Bergman PCA and Kiel JHA. Torrefaction for biomass upgrading. Proc. 14th Eur. Biomass Conf. Paris, Fr., no. October, 1721, 2005

[12] Bridgeman TG, Jones JM, Shield I, and Williams PT. Torrefaction of reed canary grass, wheat straw and willow to enhance solid fuel qualities and combustion properties. Fuel, 87: 844-856, 2008.

[13] Ferro DT, Vigouroux V, Grimm A, and Zanzi R, Torrefaction of agricultural and forest residues. Cuba. 2004.

[14] Patel B, Gami B., and Bhimani H. Improved fuel characteristics of cotton stalk, prosopis and sugarcane bagasse through torrefaction. Energy Sustain. Dev., 15(4): 372-375, 2011.

[15] Ramsey CL, Jose S, Miller DL, Cox J, Portier KM, Shilling DG, and Merritt S. Cogon grass [Imperata cylindrica (L.) Beauv.] response to herbicides and disking on a cutover site and in a mid-rotation pine plantation in southern USA. For. Ecol. Manage. 179:195-207, 2003.

[16] Shilling DG. Ecology, Physiology, and Management of Cogon grass (Imperata cylindrica). Florida Institute of Phosphate Research, Bartow, Florida USA, May 1997.

[17] Nhuchhen DR. Prediction of carbon, hydrogen, and oxygen compositions of raw and torrefied biomass using proximate analysis. Fuel, (2016). 180, 348-356.

[18] Bergman PCA, Boersma AR, Zwart RWR, and Kiel JHA. Torrefaction for biomass co-firing in existing coal-fired power stations, Energy Res. Cent. Netherlands ECN ECNC05013, no. July: 71, 2005.

[19] Demirba, A. Calculation of higher heating values of biomass fuels. Fuel, (1997). 76(5): 431-434.

[20] Chen WH., \& Kuo, PC (2011). Isothermal torrefaction kinetics of hemicellulose, cellulose, lignin and xylan using thermogravimetric analysis. Energy, 36(11): 6451-6460.

[21] Mansouri, NE El, \& Salvadó, J. Structural characterization of technical lignins for the production of adhesives: Application to lignosulfonate, kraft, soda-anthraquinone, organosolv and ethanol process lignins. Industrial Crops and Products, (2006), 24(1): 8-16.

[22] Cassel B. (n.d.). Proximate Analysis of Coal and Coke using the STA 8000 Simultaneous Thermal Analyzer.

[23] Donahue, CJ, \& Rais, EA. Proximate analysis of coal.pdf. Journal of Chemical Education, 86(2): 3. (2009). Retrieved from www.JCE.DivCHED.org

[24] Cantrell, KB., Martin II, JH., \& Ro, KS. (2010). Application of Thermogravimetric Analysis for the Proximate. ASTM International, 7(3):1-13. Retrieved from www.astm.org.

[25] Van L., S., \& Koppejan, J. (2008). Handbook of Biomass combustion and Co-firing. Earthscan.

[26] Kow, K., Yusoff, R., Aziz, A.RA, \& Abdullah, EC (2014). Characterisation of bio-silica synthesised from cogon grass (Imperata cylindrica). Powder Technology, 254: 206-213.

[27] ASTM. (2016). Standard Classificstion of Coal by ASTM D388-15. http://doi.org/10.1520/D0388-15.2

[28] Batidzirai B, Mignot APR, Schakel WB, Junginger HM, and Faaij APC, Biomass torrefaction technology: Techno-economic status and future prospects. Energy, 62:196-214, 2013.

[29] Grigiante M and Antolini D. Mass yield as guide parameter of the torrefaction process. An experimental study of the solid fuel properties referred to two types of biomass. Fuel, 153: 499-509, 2015. 